\title{
Protein folding
}
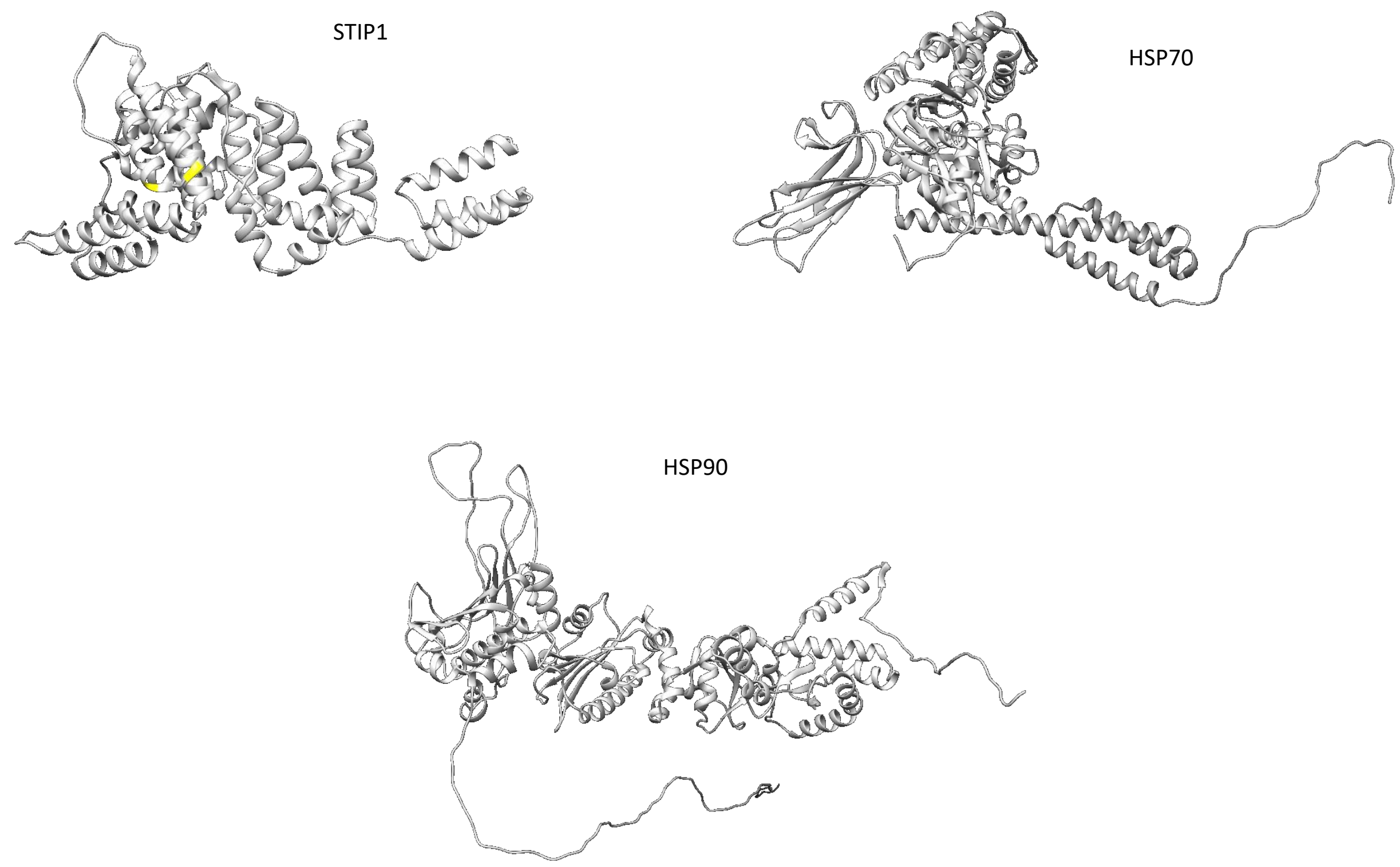


\section{Energy metabolism}
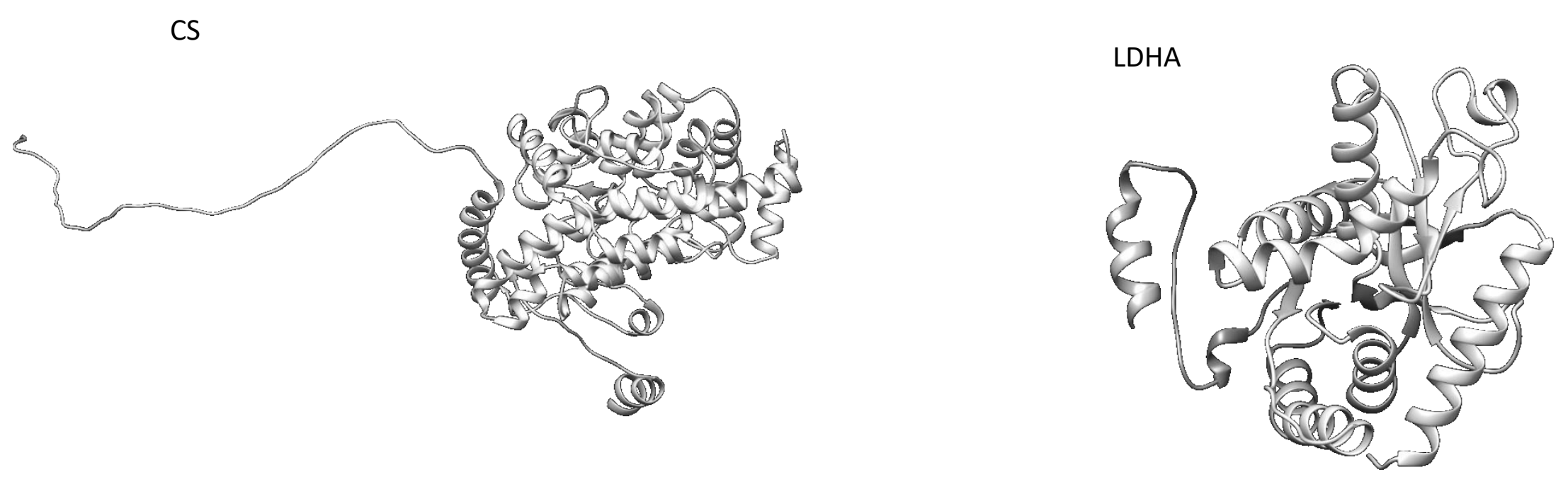

NDUFB8

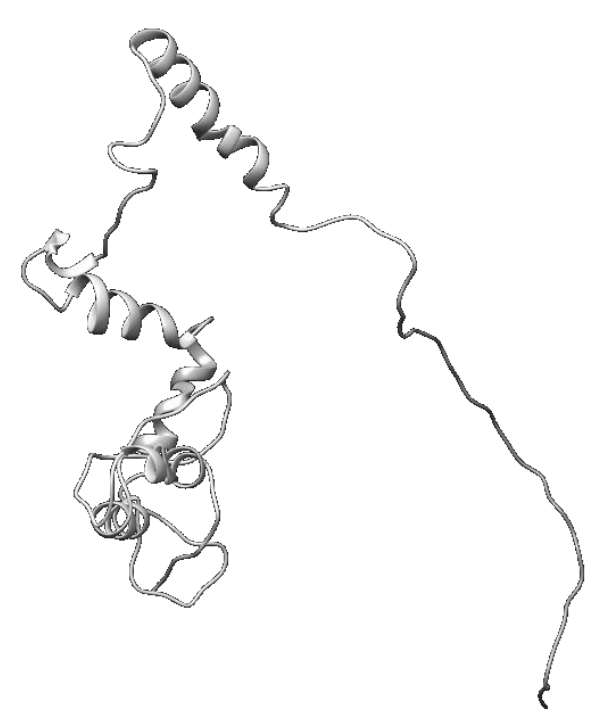

GLULA

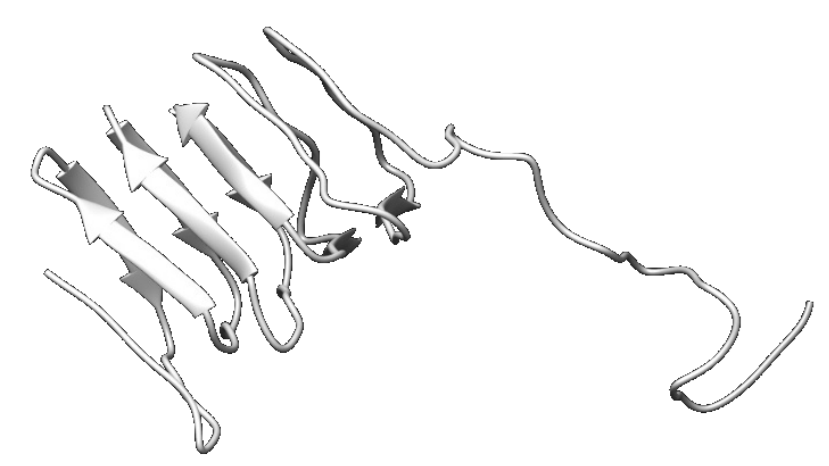

LOX

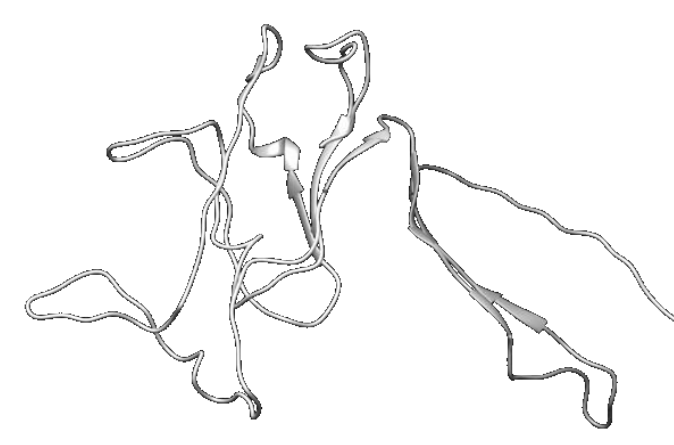


Cyrcadian rhythm
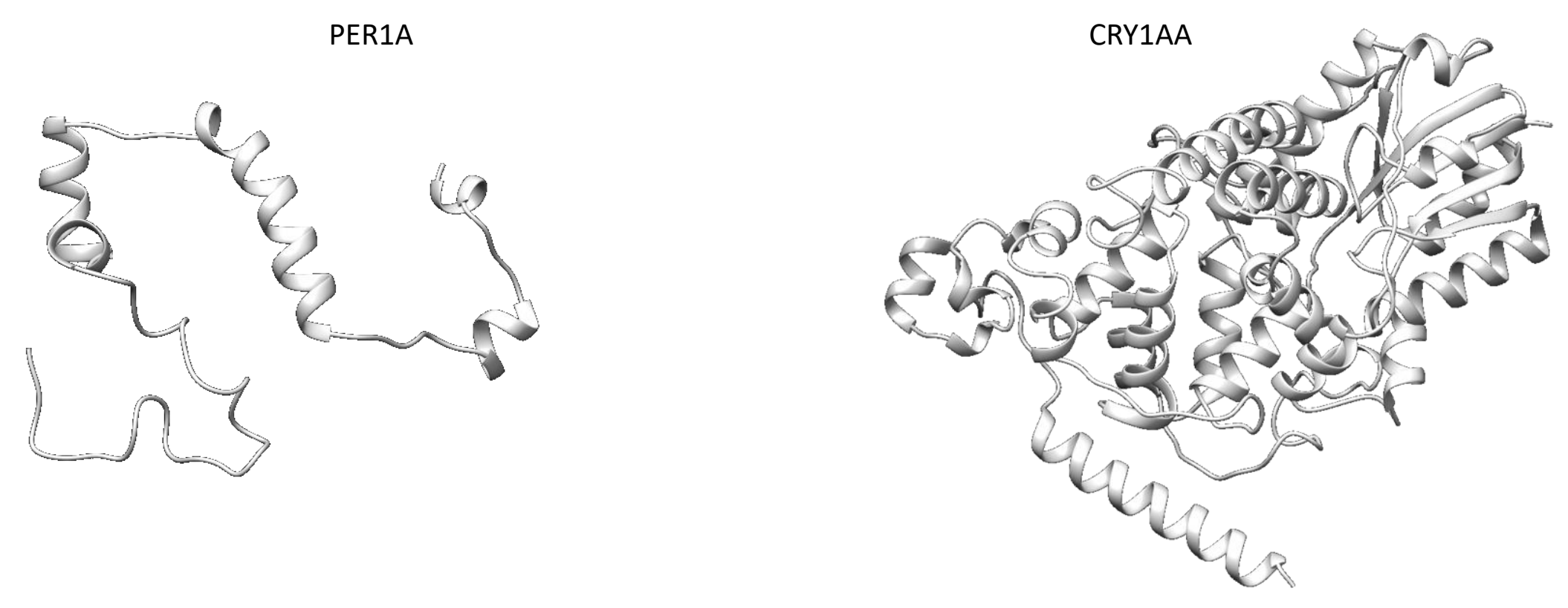